\title{
Research on Informationization of Legal Education for College Students in the Era of Big Data
}

\author{
Yangning Zheng ${ }^{1,2, *}$, Yang Yang ${ }^{1,2}$, Xiaoyu Zhang ${ }^{1}$ \\ ${ }^{1}$ Nanchang University of Technology, Nanchang, China \\ ${ }^{2}$ Bansomdejchaopraya Rajabhat University, Bangkok, Thailand \\ *Corresponding author.Email: zyn@nut.edu.cn
}

\begin{abstract}
The so-called big data is simply a collection of a large amount of data. With the passage of time and the continuous reform and innovation of the times, big data has begun to be applied in various social work and research, and has achieved quite good results, for example, big data has been applied in the legal education of college students. Therefore, in this paper, we will study and analyze the informationization of legal education for college students in the era of big data. The main purpose is to reflect the role of big data and make it play a necessary role in the development of informationization of Legal education for college students, which is beneficial to the development of big data era and Legal education for college students.
\end{abstract}

Keywords: Big Data Era, College Education, Legal Education, Education Informatization, Research and Analysis.

\section{INTRODUCTION}

As we all know, university students will enter the society for work after graduation, and from this point of view, the level of Legal education at the university level is very important, and even to some extent, it is important for the stable and smooth development of the society as a whole. Therefore, in the next article, the role, concept and characteristics of big data will be mentioned, At the same time, this paper discusses the informatization of legal education for college students under the background of big data technology, on the other hand, this paper aims to strengthen the use of big data technology in education, and promote the development of legal education towards the information level.

\section{THE CONCEPT OF BIG DATA AND ITS BASIC CHARACTERISTICS AT THE PRESENT STAGE}

\subsection{Explanation of the Concept of Big Data at the Present Stage}

The so-called big data, as the name implies, is actually a collection of contemporary massive information, the role and advantages of big data is actually very much, but in the actual application process, if this massive information for rapid analysis and application is a very difficult problem to solve, and in the past era of development, the technical aspects of the time has a relatively large limit, also cannot be applied to big data. But in recent years, China's social and economic development is relatively good, and because of this, the development of domestic technologies is also in the rising range, thus giving birth to the technology of processing these big data, these technologies can realize the rapid analysis, processing, application process of big data, so that big data can be applied in today's social work and play its role ${ }^{[1]}$.

\subsection{The Basic Characteristics of Big Data at this Stage}

\section{Huge amount of data storage sodium}

The name Big Data also indicates that Big Data has a much larger and wider range of data compared to other types of data. Because of this feature, it is almost impossible to use software and tools for processing big data that deal with unusual types of data, and in this case, more specialized software tools are needed for processing big data ${ }^{[2]}$.

2 . With a very high value 
Big data technology is very big for the change of the times, mainly because this technology will be in an important position in social work. For example, in order to carry out accurate marketing services, companies must use big data technology. At the same time, providing high-quality and efficient education services for students also needs to rely on big data technology. Therefore, we can think that the value of big data is multifaceted and plays an important role in promoting the overall progress of social civilization.

\section{Wide Range of Applications}

In the previous article has been mentioned that the scope of application of big data is very wide, because the source of the data is very wide. After the relevant research and investigation, it can be found that at this stage, the relevant domestic development enterprises attach great importance to big data, in addition, the application of big data in the education business has become more and more skilled and more extensive over time. For example, at this stage of education, big data can be used to analyze students' performance, personality, and learning style, so that more targeted education strategies can be made, which can realize the improvement of teaching effect ${ }^{[3]}$.

\section{THE REAL PROBLEMS OF LEGAL EDUCATION IN COLLEGES AND UNIVERSITIES AT THE PRESENT STAGE}

\subsection{The Concept of Legal Education is Rather Backward}

As we all know, the importance of students' mastering legal knowledge and participating in legal education is obvious, but since then, the degree of attention of universities to this work has yet to be further improved, Legal education is only an educational content attached to ideological and political education. However, it is important to know that the Legal education for college students is actually very serious, but the teaching methods of Legal education in colleges and universities at the present stage do not reach this point, and the main mode of education is simple moral education, which does not reflect the seriousness and solemnity of the Legal education. Because of the backward concept of Legal education, there are actually more problems, such as the teachers in colleges and universities are not up to the standard of legal education for college students, these reasons make the Legal education for college students at this stage produce a certain lack.

\subsection{The Teaching Method of Legal Education is very Single}

As we all know, the content of the Legal education course for college students is relatively serious, but the current college education organizations and institutions do not pay attention to this point, making the current Legal education methods are relatively single, and college students often lose interest in learning at the beginning of the course, which, over time, will have a certain impact on the formation of correct social values of college students. One of the most important manifestations is that at the present stage, most of the college students face the Legal education exams by rote memorization, although this learning and assessment method can store the knowledge of Legal education in students' minds for a short time, but once the exam process is over, college students will forget the rote memorized knowledge content, in this case, it is very difficult to form an efficient teaching process of Legal education, which will also form a certain negative effect on the formation of students' legal concept afterwards ${ }^{[4]}$.

\subsection{Curriculum Setting is not Scientific and Reasonable}

A certain investigation on the Legal education in domestic colleges and universities reveals that the lesson time of Legal education courses in colleges and universities is very short and the number of Legal education courses is very small, even only one lesson of Legal education a week, which shows that the curriculum of Legal education in colleges and universities is not scientific and reasonable. Besides, the curriculum is not scientific and reasonable because the content of Legal education courses is very single, and these single teaching contents can easily make college students enter into a boring state, and the learning effect is naturally not very ideal when they study in this state. Finally, after the actual survey, we can find that the content of Legal education is almost all set in the freshman year, and it is difficult to play the role of Legal education for college students if it does not run through the whole study period of college students ${ }^{[6]}$.

\section{EFFECTIVE MEASURES OF LEGAL EDUCATION INFORMATIZATION FOR COLLEGE STUDENTS IN THE ERA OF BIG DATA}

\subsection{Change the Concept of Legal Education at the Present Stage}

In order to promote the development of Legal education informatization of college students in the era of big data, the first thing to do is to change the concept of Legal education at this stage, in the process of changing the traditional concept, you can make certain use of big data, for this reason, you need to promote the speed of big data legal education project, and really apply big data to the work of Legal education of college students ${ }^{[15]}$. In this process, in order to ensure that the 
big data really play a role, the teacher needs to track and master the learning status and learning speed of college students in the Legal education course at all times, and record it in the form of electronic documents, when the learning status of college students has certain problems, it is necessary to use big data to carry out teaching work for college students in class, this process can be used to students' various terminal devices, over time, the development of big data era college students Legal education information technology will be very fast.

\subsection{Opening up New Channels of Legal Education}

In the current education and teaching practice, big data technology does not play an obvious role in promoting the informatization of students' legal education, and the development speed is not fast enough. This causes the legal education curriculum content is not rich, teaching methods are relatively backward, which will seriously affect the legal knowledge of college students $^{[13]}$

For example, teachers can use the Legal education network in the actual teaching process, and use some hot events and interviews of famous experts in the network to broaden the education channels, and this way can improve the effect of education after practice ${ }^{[5]}$.

\subsection{Establishing an Informatized Database of Legal Education}

In this case, the domestic government should strengthen the support ${ }^{[6]}$ and establish a relatively perfect informationized Legal education database, so that it can directly meet the needs of personalized learning of college students. And this database should meet the conditions of sharing, so as to ensure that the Legal education in different universities is fair and reasonable $\mathrm{e}^{[10]}$.

\section{CONCLUSIONS}

According to the above point of view, this paper is aimed at the premise of the rapid development of big data technology, and discusses how to use information means to carry out legal education for college students ${ }^{[13]}$. From the content described in the paper, it is easy to see that there is still a big lack of Legal education for college students at this stage, such as the traditional teaching concept is not updated, etc. In this case, the development of Legal education for college students in the era of big data should be promoted, and in the process of development afterwards, We need to go through a period of continuous improvement and supplement to enhance the legal education level of college students ${ }^{[12]}$.

This article is the research result of the key project of China's legal education in the Seventh Five Year Plan period since the founding of the people's Republic of China -- the new perspective of comprehensive legal education (aetf Seventh Five Year Plan 2019014).

\section{REFERENCES}

[1] Cui Yang, Xu Ning. Analysis of the Legal Education of College Students in the New Period in the Context of the Comprehensive Legal Education [J]. Fortune Times, 2021(02):184-185.

[2] Zhao Yuan Weijia. Research on Legal Issues in the Education and Management of Students in Xolleges and Universities [J]. Legal Expo, 2021(05):144-145.

[3] Li Dingtong. Research on Education and Propaganda of Universities According to Law in the New Era $[\mathrm{J}]$. Modern Commerce Industry, 2021,42(06):119-120.

[4] Wang Weixin. The Current Situation of College Students' Legal Literacy and Ways to Improve it [J]. Educational Teaching Forum, 2020(51):131-132.

[5] Guan Yushu. Analysis of Legal Education Management of College Students in the New era[J]. Changjiang Series, 2020(34):91-92.

[6] Luo Jun. On the New Way of College Legal Education in the New Media Era $[\mathrm{J}]$. Law and Society, 2020(33):156-157.

[7] Zhang Yang. Talking about the Construction of Ideological and Political Education System in Colleges and Universities from the Perspective of Legal Education [J]. International Public Relations, 2020(11):182-183.

[8] Pastor. Research on the Path of Improving the Legal Education Literacy of College Teachers in the New Era [J]. Law and Society, 2020(28):156-157.

[9] Yin Le,Liu Li,Zhang Tao. Research on the Current Situation of Legal Education of College Students and its Countermeasures [J]. Law and Society, 2020(26):165-166.

[10] Wang Jiucheng. Practical Research on the Construction of Legal Cultivation System in Colleges and Universities [J]. Liaoning Journal of Higher Education, 2020,22(09):5-9.

[11] Yang Yanyan, Jiang Hui. Effective Strategies for College Counselors to Enhance the Legal Education of College Students [J]. Chinese and foreign Entrepreneurs, 2020(19):195. 
[12] Lai Wu-Yun. Comparative Study on Ideological and Political Education in Chinese and American Universities [D]. Inner Mongolia University for Nationalities, 2020.

[13] Li Guyue. On the Problems and Countermeasures of Legal Education in Colleges and Universities [J]. Science and Technology Wind, 2020(17):294.

[14] Wang Junru. Exploration on the Implementation of Rule by Law in Colleges and Universities and the Legal Education in Student Work [J]. Science and Education Wenhui (Zhongjian), 2020(06):6-7.

[15] Li Wei, Liu Xiaoling, Lin Qiuyan, Li Jingxiao, Li Nan, Huang Fangyu. Exploring a New Model of Rural Legal Education Construction-- 